\title{
A RESPONSABILIDADE CIVIL OBJETIVA ATUAL DO ESTADO POR OMISSÃO
}

\section{THE CURRENT OBJECTIVE CIVIL RESPONSIBILITY OF THE STATE BY OMISSION}

\section{RAPHAELLA PARANHOS}

Acadêmica do curso de Direito - Faculdade Nacional de Educação e Ensino Superior do Paraná - FANEESP. Araucária - PR. raphaparanhos@hotmail.com

\section{VIVIANE DUARTE COUTO DE CRISTO}

Professora Orientadora - Faculdade Nacional de Educação e Ensino Superior do Paraná - FANEESP. Araucária - PR. Mestre em Direito Empresarial e Cidadania pelo Centro Universitário Curitiba - UNICURITIBA. viviane@duartecristo.com.br

\section{RESUMO}

A Constituição Federal de 1966, em seu artigo 37 §6º prevê que o Estado tem o dever de indenizar os particulares pelos danos patrimoniais ou morais causados por seus agentes, em decorrência do exercício da função administrativa. Para tanto é necessário o preenchimento de três pressupostos: a conduta, o dano causado pelo agente e o nexo de causalidade entre ambos. O dolo e a culpa são elementos subjetivos da responsabilidade, apenas considerados em ação movida pelo particular contra o agente público que causou o dano, ou em caso de ação de regresso do Estado em face deste agente. Essa responsabilidade é extracontratual por vincular-se a danos sofridos em relações jurídicas de sujeição geral. A teoria aplicada atualmente, desde 194, para a responsabilidade do Estado é a objetiva, 


\section{Personalidade Acadêmica Homenageada:}

Augustus B. Cochran III (Agnes Scott College)

chamada também de teoria da responsabilidade sem culpa ou teoria publicista, que afasta a necessidade de comprovação de culpa ou dolo do agente público e fundamenta o dever de indenizar na noção de risco. A respeito da responsabilidade objetiva, existem duas correntes distintas: a teoria do risco integral e a do risco administrativo. A teoria do risco administrativo se opõe a teoria do risco integral que defende que o Estado tem o dever de indenizar todo e qualquer dano, essa teoria é utilizada em casos excepcionais definidos pela jurisprudência, como nos casos de dano ambiental. No ordenamento jurídico a regra é a aplicação da teoria do risco administrativo, onde reconhece excludentes da responsabilidade estatal, que são três: o caso fortuito ou força maior, culpa exclusiva da vítima ou culpa exclusiva de terceiros. No caso fortuito ou força maior, como são acontecimentos involuntários, imprevisíveis ou incontroláveis é rompido o nexo de causalidade entra a ação estatal e o prejuízo sofrido pelo particular. Na culpa exclusiva da vítima o prejuízo é consequência da intenção deliberada do próprio prejudicado e na terceira e última excludente, a culpa de terceiros ocorre quando o prejuízo pode ser atribuído a pessoa estranha aos quadros da Administração Pública. Em se tratando da teoria do risco integral, quando não se aplicam excludentes, é cabível em situações excepcionais como: acidentes de trabalho infortunísticas, indenização coberta pelo seguro obrigatório para automóveis (DPVAT), atentados terroristas em aeronaves, dano ambiental e dano nuclear. Há consenso de que os danos causados pelas ações do Estado geram dever objetivo de indenizar, porém há divergência quanto às omissões. Nesse caso, em regra, a responsabilidade civil do Estado é subjetiva, além da presença do dolo e da culpa, há necessidade de um elemento específico: a culpa administrativa. São adeptos da corrente subjetiva nos casos de omissão: José Cretella Júnior, Yussef Said Cahali, Álvaro Lazzarini, Oswaldo Aranha Bandeira de Mello e Celso Antônio Bandeira de Mello. A omissão é a prova de que o serviço público ou não funcionou, ou funcionou de forma ineficiente ou tardia, porém a jurisprudência tem se posicionado com a adoção de responsabilidade objetiva quando o Estado tiver o dever legal de impedir o dano, mas não cumpriu com a sua função. Exemplo disso está na morte da pessoa presa, quando o Estado tem sido objetivamente responsabilizado, em razão do seu dever específico de proteção 
Personalidade Acadêmica Homenageada:

Augustus B. Cochran III (Agnes Scott College)

previsto no artigo $5^{\circ}$ da CF, ou seja, o Estado tem o dever de assegurar a integridade física e moral das pessoas durante o período de custódia, sendo dispensado desta incumbência se a morte não podia ser evitada, caso em que será rompido o nexo causal entre a morte e a omissão estatal. O método utilizado foi o dedutivo, partindo-se de análise da legislação aplicável, doutrina e jurisprudência, com a verificação da evolução da responsabilidade do Estado em casos de omissão.

PALAVRA-CHAVE: Responsabilidade Civil; Omissão do Estado; Responsabilidade Subjetiva; Responsabilidade Subjetiva.

\section{REFERÊNCIAS}

DIAS, Clara; CARVALHO, Ana. Responsabilidade civil do Estado: breve panorama evolutivo do direito brasileiro. Revista Jurídica, Curitiba, v. 3, n. 48, p. 335-357, 2017.

GONÇALVES, Carlos Roberto. Direito civil brasileiro. 18. Ed. Rio de Janeiro: Saraiva, 2019.

LENZA, Pedro e GONÇALVES, Carlos Roberto. Direito civil esquematizado. 4. ed., Rio de Janeiro: Saraiva, 2016. 